\title{
Title Long-term warming effects on the microbiome and nitrogen fixation of a common moss species in sub-Arctic tundra
}

Ingeborg J. Klarenberg ${ }^{1,2}$, Christoph Keuschnig ${ }^{3}$, Ana J. Russi Colmenares ${ }^{2}$, Denis Warshan ${ }^{2}$, Anne D. Jungblut ${ }^{4}$, Ingibjörg S. Jónsdóttir ${ }^{2}$, Oddur Vilhelmsson ${ }^{1,5,6}$

${ }^{1}$ Natural Resource Sciences, University of Akureyri, Borgir i Nordurslod, 600 Akureyri, Iceland

${ }^{2}$ Faculty of Life and Environmental Sciences, University of Iceland, Sturlugata 7, 102 Reykjavík, Iceland

${ }^{3}$ Environmental Microbial Genomics, Laboratoire Ampère, CNRS, École Centrale de Lyon, Écully, France

${ }^{4}$ Life Sciences Department, The Natural History Museum, London, United Kingdom

${ }^{5}$ BioMedical Center, University of Iceland, Reykjavík, Iceland

${ }^{6}$ School of Biological Sciences, University of Reading, Reading, United Kingdom

Corresponding author:

Ingeborg J. Klarenberg

Borgir i Nordurslod, 600 Akureyri, Iceland

ingeborg.klarenberg@gmail.com, +31655765420 


\section{Abstract}

2

3

1. Bacterial communities form the basis of biogeochemical processes and determine plant growth and health. Mosses, an abundant plant group in Arctic ecosystems, harbour diverse bacterial communities that are involved in nitrogen fixation and carbon cycling. Global climate change is causing changes in aboveground plant biomass and shifting species composition in the Arctic, but little is known about the response of moss microbiomes.

2. Here, we studied the total and potentially active bacterial community associated with Racomitrium lanuginosum, in response to 20-year in situ warming in an Icelandic heathland. We evaluated the effect of warming and warming-induced shrub expansion on the moss bacterial community composition and diversity, nifH gene abundance and nitrogen-fixation rates.

3. Warming changed both the total and the potentially active bacterial community structure, while litter abundance only affected the total bacterial community structure. The relative abundance of Proteobacteria increased, while the relative abundance of Cyanobacteria and Acidobacteria decreased. NifH gene abundance and nitrogen-fixation rates were negatively affected by litter and Betula nana abundance, respectively. We also found shifts in the potentially nitrogen-fixing community, with Nostoc decreasing and non-cyanobacterial diazotrophs increasing in relative abundance. Our data suggests that the moss microbial community including the potentially nitrogen-fixing taxa is sensitive to future warming.

4. Synthesis. Long-term warming led to a shift in moss-associated bacterial community composition, while the abundance of nitrogen-fixing bacteria and nitrogen-fixation rates were negatively affected by increased litter and Betula nana abundance respectively. Warming and increased shrub abundance as a result of 

rates in tundra ecosystems.

\section{$28 \quad$ Keywords}

29 Moss, microbiome, climate change, tundra, nitrogen fixation, shrub expansion 
 \\ Introduction}

Temperature in high-latitude regions is rising twice as fast as elsewhere (IPCC, 2019),

which is predicted to have large impacts on Arctic ecosystems, for instance by altering species distributions and interactions (Van der Putten, 2012; Wookey et al., 2009). One such interaction that might be affected by warming is the association between mosses and bacterial communities as well as related ecosystem processes such as pedogenesis, carbon (C) cycling, and nitrogen $(\mathrm{N})$ cycling.

Bryophytes, mosses in particular, comprise a large component of the vegetation in many high-latitude ecosystems (Longton, 1992). They play important roles in biogeochemical cycles by forming a $\mathrm{C}$ sink via their slow decomposition rates, by accounting for up to $7 \%$ of terrestrial net primary productivity and by supporting up to half of the terrestrial $\mathrm{N}_{2}$-fixation (Cornelissen et al., 2007; 2012; Porada et al., 2013; Turetsky, 2003; Turetsky et al., 2012). Most mosses consist of a upper living segment with photosynthetic tissue and a lower decaying dead segment and thus link above-ground and belowground processes (Whiteley \& Gonzalez, 2016). Mosses provide a habitat for a range of microbiota, microfauna and mesofauna (Lindo \& Gonzalez, 2010). These moss-associated microorganisms are involved in the decomposition of dead moss tissue (Kulichevskaya et al., 2007) and some of them are active diazotrophs (Chen et al., 2019). $\mathrm{N}_{2}$-fixation by mossassociated Cyanobacteria, the best studied of these diazotrophs, was shown to directly increase moss growth rates (Berg et al., 2013) and thereby control C sequestration in moss tissues. Moss-associated diazotrophy is also an important source of new available $\mathrm{N}$ in boreal and Arctic ecosystems (DeLuca et al., 2002; Rousk et al., 2017). In order to understand the implications of climate change for the role of mosses in ecosystem $\mathrm{C}$ and $\mathrm{N}$ cycling, we need to understand how moss-associated microbial communities react to elevated temperatures. 

environmental factors such as $\mathrm{pH}$ and nutrient availability (Bragina, Berg, et al., 2012; Holland $\square$ Moritz et al., 2018; Tang et al., 2016). While Cyanobacteria have received most of the attention for their $\mathrm{N}_{2}$-fixing capability (Berg et al., 2013; Gentili et al., 2005; Ininbergs et al., 2011; Lindo et al., 2013; Rousk et al., 2013; Stewart, Lamb, et al., 2011; Warshan et al., 2016, 2017), mosses harbour diverse bacterial communities. Commonly found phyla associated with mosses include Acidobacteria, Actinobacteria, Armatimonadetes, Bacteroidetes, Cyanobacteria, Planctomycetes, Proteobacteria and Verrucomicrobia (Kostka et al., 2016; Tang et al., 2016), and their potential functions include $\mathrm{N}_{2}$-fixation (Bragina, Maier, et al., 2012), anoxygenic phototrophy (Holland $\square$ Moritz et al., 2018) and freeze protection (Raymond, 2016). The bacterial community composition of mosses has primarily been studied for peat and feather mosses, but we know little about the bacterial communities of other moss species. For instance, little is known about the bacterial community associated with ecologically important moss species such as Racomitrium lanuginosum (Hedw.) Brid. This moss species has a wide distribution at high altitudes in temperate regions of the Northern and Southern Hemisphere and at low altitudes in the Arctic (Jonsdottir et al., 1995; Tallis, 1995). It is a dominant species in many Icelandic ecosystems, forming dense mats where conditions are favourable for colonisation and growth (Bjarnason, 1991; Ingimundardóttir et al., 2014; Tallis, 1958).

Despite the importance of microbial communities for plant functioning and ecosystem processes, the long-term effect of warming on moss microbial communities has received little attention. Two studies describing the effect of four weeks to two years warming-related changes in peat moss bacterial community composition, reported a decrease in overall bacterial and diazotrophic diversity with higher temperatures in situ and under laboratory conditions (Carrell et al., 2019; Kolton et al., 2019). Whether this warming-induced decrease 
in diversity also holds for bacterial communities associated with other moss species in high latitudes is unknown. Moreover, decades-long-warming effects on moss-associated bacterial communities have yet to be explored.

Nonetheless, the effect of warming on some high-latitude plant communities has been better documented, where for instance ambient and experimental warming (ranging from 5-43 years) in tundra heaths have resulted in shrub expansion (Bjorkman et al., 2020; Myers-Smith et al., 2011; Myers $\square$ Smith et al., 2019). The increase in deciduous dwarf shrubs, for example Betula nana, led to an increase in the quantity of relatively high quality litter, resulting in a faster turnover of the overall leaf litter C and N (McLaren et al., 2017). This warming-induced change in litter quality and nutrient cycling might also affect the composition of microbial communities (Deslippe et al., 2012). Indeed, changing litter inputs can consequently lead to shifts in moss microbiomes (Jean et al., 2020). The increase in labile shrub litter may lead to an increase in copiotrophic taxa and decrease in oligotrophic taxa (Fierer et al., 2007; Wallenstein et al., 2007). Warming might thus also, indirectly, via a change in leaf litter quality and quantity resulting from increasing shrub biomass, lead to changes in the bacterial communities associated with the moss layer. Changes in bacterial community composition could consequently affect $\mathrm{N}_{2}$-fixation rates (Wu et al., 2020). In addition, $\mathrm{N}_{2}$-fixation rates can be expected to increase with temperature, as metabolic process rate in microorganisms increases with temperature and the enzyme nitrogenase is more active at higher temperatures than average Arctic temperatures (Houlton et al., 2008). Temperature-induced drought, however, can inhibit $\mathrm{N}_{2}$-fixation rates, especially cyanobacterial $\mathrm{N}_{2}$-fixation (Rousk et al., 2014, 2015, 2018; Stewart, Coxson, et al., 2011; Stewart et al., 2014; Stewart, Lamb, et al., 2011; Whiteley \& Gonzalez, 2016; Zielke et al., 2005). Indirect effects of temperature on $\mathrm{N}_{2-}$ fixation rates might also be related to physiological adaptation of diazotrophic communities (Whiteley \& Gonzalez, 2016), or shifts to a species composition better suited to the new 
conditions (Deslippe et al., 2005; Rousk et al., 2018; Rousk \& Michelsen, 2017). Warminginduced changes in bacterial species composition could potentially feedback to the abundance, diversity and/or $\mathrm{N}_{2}$-fixation activity of diazotrophs, through alteration of biotic interactions between bacteria e.g. competition and/or cooperation (Ho et al., 2016). The increase in shrubs might also affect $\mathrm{N}_{2}$-fixation rates, either negatively via an increase in shading leading to an decrease in $\mathrm{N}_{2}$-fixation rates, or either inhibit or promote $\mathrm{N}_{2}$-fixation depending on the nutrient content of the litter (Rousk \& Michelsen, 2017; Sorensen \& Michelsen, 2011).

In this study we investigated how two decades of experimental warming with open top chambers impact the bacterial community and $\mathrm{N}_{2}$-fixation rates associated with the prevailing moss $R$. lanuginosum (Hedw.) Brid in a subarctic-alpine dwarf shrub heath in northern Iceland, dominated by B. nana.

We hypothesised that long-term warming directly and/or indirectly via the warminginduced increase in labile $B$. nana litter (1) leads to a shift in bacterial community composition with a decrease in bacterial diversity and (2) leads to a decrease in oligotrophic taxa and an increase in copiotrophic taxa. Further, we hypothesised (3) that changes in $\mathrm{N}_{2^{-}}$ fixation rates will depend on the combination of the direct effect of warming leading to an increase in $\mathrm{N}_{2}$-fixation rates and indirect effects of warming. These indirect effects include shading leading to a decrease in $\mathrm{N}_{2}$-fixation rates; increased litter leading to an increase or a decrease in $\mathrm{N}_{2}$-fixation rates; and/or changes in the bacterial community that could mediate the effects of warming, shading and/or litter on $\mathrm{N}_{2}$-fixation rates. To address these hypotheses, we sampled $R$. lanuginosum in a warming simulation experiment in the northwest highlands of Iceland that has been running for 20 years (Jonsdottir et al., 2005). We assessed the associated bacterial community structure by $16 \mathrm{~S}$ rRNA gene and rRNA amplicon sequencing, $\mathrm{N}_{2}$-fixation rates with acetylene reduction assays (ARA), and $\mathrm{N}_{2}$-fixation 
129 potential using quantitative PCR (qPCR) of the nifH gene encoding the iron-protein

130 component of the nitrogenase.

131

132

133

134

135

136

137

138

139

140

141

142

143

144

145

146

147

148

149

150

151

152

\section{Methods}

\section{Field site and experimental design}

The sampling was conducted in permanent plots of a long-term warming simulation experiment at Auðkúluheiði in the northwest highlands of Iceland $\left(65^{\circ} 16^{`} \mathrm{~N}, 20^{\circ} 15^{\prime} \mathrm{W}, 480 \mathrm{~m}\right.$ above sea level). The site is a part of the International Tundra Experiment (ITEX; Henry and Molau 1997) and according to Köppen's climate definitions, the sampling site is situated within the lower Arctic (Köppen, 1931). The vegetation has been characterized as a relatively species-rich dwarf shrub heath, with $B$. nana being the most dominant vascular species and R. lanuginosum and Cetraria islandica as the dominating moss and lichen species (Jonsdottir et al., 2005). The experimental site has been fenced off since 1996 to prevent sheep from disturbing the experiment.

Ten plot pairs of $75 \times 75 \mathrm{~cm}$ were selected and one of the plots in each pair was randomly assigned to a warming treatment while the other served as a control. Open top plexiglass chambers (OTCs) were set up in August 1996 and 1997 to simulate a warmer summer climate and have been in place throughout the year ever since (Hollister \& Webber, 2000; Jonsdottir et al., 2005). The temperature in the OTCs was on average $1.4{ }^{\circ} \mathrm{C}$ higher in June 2016 to August 2016 and $0.22{ }^{\circ} \mathrm{C}$ higher from August 2018 to June 2019 (Table S1). Relative humidity was $-3 \%$ lower in the OTCs in June 2016 to August 2016 (Table S1).

The vegetation responses were monitored by a detailed vegetation analysis after peak biomass at a few year intervals using the point intercept method following standard protocols of the International Tundra Experiment (Molau \& Mølgaard, 1996): 100 points per plot, all hits (intercepts) per species recorded in each point through the canopy; relates to biomass) 
153 (Jonsdottir et al., 2005). In this study we use data from August 2014 on abundance (total

154 number of hits per plot) for R. lanuginosum, B. nana and litter to test hypotheses 1-3 (Table

155 S2). In 2014 the abundance of $R$. lanuginosum was on average 0.8 times lower in the warmed

156 plots than control plots, but not significantly, while the abundance of B. nana was 2.5 times

157 greater in the warm plots on average and litter was 2.7 times greater (Table S2).

\section{RNA and DNA extraction and sequencing}

To assess overall bacterial community structure and bacterial diversity (hypothesis 1 and 2) associated with $R$. lanuginosum we collected moss shoots, extracted DNA and RNA and used 16S rRNA gene amplicon sequencing. For RNA and DNA extraction we collected R. lanuginosum moss shoots in June 2017. Per warmed (OTC) and control plot, five moss shoots were collected with sterile tweezers. In total 50 OTC and 50 control samples were collected. The moss shoots were immediately soaked in RNAlater (Ambion) to prevent RNA degradation and kept cool until storage at $-80{ }^{\circ} \mathrm{C}$. Prior to extraction, the samples were rinsed with RNase free water to remove soil particles and RNAlater and ground for six minutes using a Mini-Beadbeater and two sterile steel beads. RNA and DNA were extracted simultaneously using the RNeasy PowerSoil Total RNA Kit (Qiagen) and the RNeasy PowerSoil DNA Elution Kit (Qiagen), following the manufacturer's instructions. DNA and RNA concentrations were determined with a Qubit Fluorometer (Life Technologies) and quality was assessed with a NanoDrop (NanoDrop Technologies) and Bioanalyzer (Agilent Technologies). cDNA was synthesized using the High-Capacity cDNA Reverse Transcription Kit (Thermofisher) following the manufacturer's instructions and quantified on a Qubit Fluorometer (Life Technologies). All DNA extractions (100 samples) were used for qPCR. From all DNA and cDNA samples, we selected 48 DNA samples (24 from each treatment) and 48 cDNA samples (24 from each treatment) for sequencing based on RNA and DNA quality and quantity. Library preparation and sequencing of the V3-V4 region of the $16 \mathrm{~S}$ 
rRNA gene on an Illumina MiSeq platform ( 2 x 300 bp) was performed by Macrogen, Seoul, using MiSeq v3 reagents and the primer pair 337F/805R and the PCR conditions described in (Klindworth et al., 2013).

\section{Sequence processing}

In order to obtain high-resolution data and to better discriminate ecological patterns, we processed the raw sequences using the DADA2 (version 1.12.1) pipeline (Callahan et al., 2016, 2017), which does not cluster sequences into operational taxonomic units (OTUs), but uses exact sequences or amplicon sequence variants (ASVs). Forward reads were truncated at $260 \mathrm{bp}$ and reverse reads at $250 \mathrm{bp}$. Assembled ASVs were assigned taxonomy using the Ribosomal Database Project (RDP) naïve Bayesian classifier (Q. Wang et al., 2007) in DADA2 and the SILVA_132 database (Quast et al., 2013). We removed samples with less than 10.000 non-chimeric sequences (11 samples) and we removed ASVs assigned to chloroplasts and mitochondria, singletons, as well as ASVs present in only one sample. In total, for 85 samples, 3598 ASVs remained with an average read size of 448 bp after DADA2. To account for uneven sequencing depths, the data were normalised using cumulative-sum scaling (CSS) (Paulson et al., 2013). The 16S rRNA gene based community is hereafter sometimes referred to as the 'total bacterial community' and the 16S rRNA (cDNA) based community is hereafter referred to as the "potentially metabolically active bacterial community', acknowledging that $16 \mathrm{~S}$ rRNA is not a direct indicator of activity but rather protein synthesis potential (Blazewicz et al., 2013). Raw sequences are available in the European Nucleotide Archive under accession number PRJEB40635.

\section{Quantitative real-time PCR of nifH and $16 \mathrm{~S}$ rRNA genes}

We used the DNA samples (100 samples (50 control and 50 OTC samples)) for quantification of nifH and 16S rRNA genes (to test hypothesis 3). This was performed by quantitative PCR (Corbett Rotor-Gene) using the primer set PolF/PolR and 341F/534R 
203 respectively (Poly et al., 2001). The specificity of the nifH primers for our samples was

204 confirmed by SANGER sequencing of 10 clone fragments. Standards for nifH reactions were

205 obtained by amplifying one cloned nifH sequence with flanking regions of the plasmid vector

206 (TOPO TA cloning Kit, Invitrogen). Standard curves were obtained by serial dilutions $(\mathrm{E}=$

$2070.9-1.1, \mathrm{R}^{2}=>0.99$ for all reactions). Each reaction had a volume of $20 \mu \mathrm{L}$, containing $1 \mathrm{x}$

208 QuantiFast SYBR Green PCR Master Mix (Qiagen), $0.2 \mu \mathrm{L}$ of each primer $(10 \mu \mathrm{M}), 0.8 \mu \mathrm{L}$

209 BSA $(5 \mu \mathrm{g} / \mu \mathrm{L}), 6.8 \mu \mathrm{L}$ RNase free water and $2 \mu \mathrm{L}$ template. The cycling program was 5 min

210 at $95{ }^{\circ} \mathrm{C}, 30$ cycles of $10 \mathrm{~s}$ at $95^{\circ} \mathrm{C}$ and $30 \mathrm{~s}$ at $60^{\circ} \mathrm{C}$.

211

212

\section{Acetylene reduction assays}

We used acetylene reduction assays (ARA) to estimate $\mathrm{N}_{2}$-fixation rate to test hypothesis 3. We followed the procedure described in DeLuca et al. (2002) and Zackrisson et al. (2004). We collected three moss shoots of $5 \mathrm{~cm}$ length per control plot and OTC in June and August 2014. The three shoots per plot were analysed separately. The moss shoots were placed in $20 \mathrm{~mL}$ vials with $2 \mathrm{~mL}$ deionized water. Moss shoots were acclimated in a growth chamber for $24 \mathrm{~h}$ at $10{ }^{\circ} \mathrm{C}$ and $200 \mu \mathrm{mol} \mathrm{m} \mathrm{s}^{-2}$ PAR. $10 \%$ of the headspace was replaced by acetylene. After an additional $24 \mathrm{~h}$ of incubation in the growth chamber under the same conditions, acetylene reduction and ethylene production were measured by gas chromatography.

\section{Statistical analysis}

All statistical analyses were performed in R (version 3.6.3). Richness (number of ASVs) and Shannon diversity were calculated with the R packages 'vegan' (version 2.5-4) (Oksanen et al., 2013) and 'phyloseq' (version 1.28.0) (McMurdie \& Holmes, 2013). Differences in $\mathrm{N}_{2}$-fixation rates, $16 \mathrm{~S}$ rRNA and nifH gene abundance, ASV richness and Shannon diversity (hypothesis 1) between the control and warmed plots were assessed with generalised linear mixed models using a Bayesian method that relies on Markov Chain Monte 
Carlo (MCMC) iterations. In these models we treated treatment (control or OTC), B. nana

abundance and litter abundance as fixed factors and plot as a random factor to account for repeated sampling within plots, using the R package 'MCMCglmm' (version 2.29) (Hadfield,

2010). For all models, we used as many iterations as necessary to allow for model between the control and warmed estimates were based on the posterior mode estimates and the 95\% Highest Posterior Density Credible Intervals.

We tested the effect of treatment, $B$. nana abundance and litter abundance on the bacterial community composition with PERMANOVAs (Anderson, 2001). All PERMANOVAs were based on Bray-Curtis distance matrices and were performed using the adonis function in the R package 'vegan' (version 2.5-6). We also tested whether samples taken from the same plot were similar to each other using PERMANOVAs. Plot indeed had a significant effect on the cDNA-based bacterial community composition, but not on the DNAbased bacterial community composition (Table S3 and S4). To reduce possible biases related to samples coming from the same plot, we used plot as strata in the PERMANOVAs testing the effect of treatment, B. nana abundance and litter abundance. In this way we controlled for the variation caused by repeated sampling within plots by limiting permutations within plots.

The relative abundances of taxa on phylum, class and order level between the warmed and the control samples (hypothesis 2) were tested using Wilcoxon rank-sum tests on plot

247 averages (samples from the same plot were pooled for this purpose) using the stat_compare_means function from the R package 'ggpubr' (version 0.2.1) (Kassambara, 2020).

Two methods were used to determine taxa on ASV level sensitive to warming 
253 normalised datasets (with pseudoreplicates pooled per plot) with the R package 'DESeq2'

254 (version 1.24.0) (Love et al., 2014). The adjusted $P$-value cut-off was 0.1 (Love et al., 2014).

255 Differential abundance analysis only uses ASVs present in both the OTC and control samples.

256 The second method we used to find taxa sensitive to warming, was the indicator species

257 analysis. To find bacterial taxa indicative for the warming or the control treatment,

258 correlation-based indicator species analysis was done with all possible site combinations

259 using the function multipatt of the R package 'indicSpecies' (version 1.7.6) (De Caceres \&

260 Legendre, 2009) based on $10^{3}$ permutations. For this, we pooled all samples originating from

261 the same plot. The indicator species analysis takes into account ASVs present in both OTC

262 and control samples, but also ASVs present in only one of the treatments. We combined

263 results of the DESeq2 and indicator species analysis into a final list of ASVs sensitive to

264 warming. Data are presented as the number of significant ASVs identified in DESeq2 and/or

265 indicator species analysis and represented at the genus level.

266 To test hypothesis 3, we used structural equation modelling to estimate the direct and

267 indirect effects of warming on the bacterial community and the consequences for $\mathrm{N}_{2}$-fixation.

268 The structural equation models were fitted using the R package 'lavaan' (version 0.6-7).

269 Initial models were constructed using current knowledge and hypotheses of effects of

270 warming on plant-microbe interactions and on $\mathrm{N}_{2}$-fixation activities. As variables included in

271 the model, we used treatment, litter abundance, B. nana abundance, 16S rRNA abundance,

272 nifH abundance, $\mathrm{N}_{2}$-fixation rates and 'bacterial community structure'. The latter is a latent

273 variable which consisted of the average of $\beta$-diversity and Shannon diversity index per plot

274 for the combined cDNA and DNA data. $\beta$-diversity was derived from the first axis of a PCoA

275 analysis. All variables were averaged per plot. We tested whether the model has a significant

276 model fit according to the following criteria: $\chi 2 / \mathrm{df}<2, \mathrm{P} \square$ values $(P>0.05)$, root mean 
277 square error of approximation (rmsea) $<0.07$ and goodness of fit index $(\mathrm{GFI})>0.9$ (Hooper

278 et al., 2008).

279 Results

Treatment effect on bacterial diversity and community structure

The richness and Shannon diversity of the DNA-based and the cDNA-based bacterial

S3). However, we found a negative effect of B. nana abundance on the richness and Shannon diversity $\mathrm{pMCMC}=0.01$, Figs 1c-1d).

The PERMANOVA showed that treatment significantly influenced the DNA- and the cDNA-based community compositions of the moss (DNA: $\mathrm{R}^{2}=0.05$, and $P<0.001$ and cDNA: $\mathrm{R}^{2}=0.04$, and $P<0.001$; Table S6 and S7). In addition to the warming treatment,

litter abundance also significantly influenced the DNA-based bacterial community composition $\left(\mathrm{R}^{2}=0.03, P=0.05\right)$, but not the cDNA-based bacterial community composition (Table S6 and S7).

\section{Taxonomic composition $\boldsymbol{R}$. lanuginosum-associated bacterial communities}

In the control samples, where bacterial communities were under ambient

environmental conditions, the most abundant phyla in the DNA and cDNA samples included

Proteobacteria (44\% and $40 \%$ average relative abundance across all control DNA and cDNA samples respectively), followed by Acidobacteria (DNA: 29\%, cDNA: 23\%), Actinobacteria 
301 Acetobacterales (DNA: 15\%, cDNA: 21\%), Myxococcales (DNA: 12\%, cDNA: 7\%),

302 Caulobacterales (DNA: 6\%, cDNA 3\%) and Rhizobiales (DNA: 6\%, cDNA 5\%) were the

303 most abundant orders of the Proteobacteria (Fig. S1). The order Acetobacterales was

304 dominated by the genus Acidiphilium (DNA: 5\%, cDNA 8\%), the order Myxococcales was

305 dominated by the genus Haliangium (DNA: 4\%, cDNA 3\%) (Fig. S2).

306 The Acidobacteria were dominated by the orders Acidobacteriales (DNA: 17\%, cDNA

307 16\%) and Solibacterales (DNA: 11\%, cDNA: 7\%) (Fig. S1). The Acidobacteriales were 308 dominated by the genus Granulicella (DNA: 11\%, cDNA: 7\%). The Solibacterales were 309 dominated by the genera Bryobacter (DNA: 5\%, cDNA 2\%) and Candidatus Solibacter 310 (DNA: 6\%, cDNA: 5\%) (Fig. S3).

Actinobacteria mainly comprised the orders Solirubrobacterales (DNA: 5\%, cDNA: 8\%) and Frankiales (DNA: 2\%, cDNA: 4\%) (Fig. S1).

Treatment effect on the relative abundances of bacterial taxa on phylum, class and order level

We compared the relative abundances of taxa on phylum, class and order level in the controls with the warmed samples from the OTCs (Fig. 2 and Fig. S1). On phylum level, Acidobacteria (Wilcoxon rank-sum test, $P=0.008)$, Cyanobacteria $(P=0.03)$ and Gemmatimonadetes $(P=0.02)$ decreased in relative abundance with warming, while

321 Proteobacteria $(P=0.04)$ increased in relative abundance in the DNA-based bacterial 322 communities (Fig. 2a). We did not detect significant changes in the cDNA-based bacterial communities on phylum level. 
On class level, Acidobacteriia $(P=0.01)$, Gemmatimonadetes $(P=0.02)$, and

Oxyphotobacteria $(P=0.03)$ decreased in relative abundance under warming in the DNA-

based bacterial communities, while Gammaproteobacteria $(P=0.04)$ increased in relative

abundance in the DNA- and the cDNA-based bacterial communities (Fig. 2b).

At the order level, Betaproteobacteriales (DNA: $P=0.04$, cDNA: $P=0.005$ ) and

Micrococcales (DNA: $P=0.007$, cDNA: $P=0.0007$ ) had a higher relative abundance in the

warmed DNA- and cDNA-based bacterial communities (Fig. S1). Acidobacteriales (DNA: $P$

$331=0.03$, cDNA: $P=0.04)$ showed a lower relative abundance in the warmed DNA- and

cDNA-based bacterial communities (Fig. S1). In addition, in the DNA-based bacterial

communities, Sphingobacterales $(P=0.05)$ and Cytophagales $(P=0.02)$ increased in relative

abundance under warming. Nostocales $(P=0.03)$ decreased in relative abundance under

warming. In the cDNA-based bacterial communities, the orders Sphingomonadales $(P=0.02)$

and Rhizobiales $(P=0.02)$ increased in relative abundance under warming, while

Acetobacterales $(P=0.05)$ decreased in relative abundance under warming (Fig. S1).

\section{Treatment related shifts in the relative abundance of ASVs}

For the bacterial communities in the DNA-based analysis, DESeq2 and indicator

species analysis combined revealed 23 ASVs significantly higher in relative abundance under

warming and 122 ASVs with higher relative abundance in the controls (Table S8). The

strongest indicator species for the control plots corresponded to the taxa that were more

abundant in the control plots according the DESeq2 analysis. ASVs with increased relative

abundance in the warmed samples belonged to the genera Allorhizobium-Neorhizobium-

Pararhizobium-Rhizobium, Nitrobacter (Alphaproteobacteria), and Galbitalea

346 (Actinobacteria). ASVs with increased relative abundance in the controls belonged to the

347 genera Acidipila, Bryocella, Bryobacter, Candidatus Solibacter and Granulicella 
348 (Acidobacteria), Acidiphilium, Endobacter, and Bradyrhizobium (Alphaproteobacteria),

349 Nostoc (Cyanobacteria), and Conexibacter (Actinobacteria) (Fig. 3 and Table S8).

active ASVs with higher abundance in the control plots and 14 potentially active ASVs more

abundant in the warmed plots (Fig. 3, Table S9). ASVs more abundant in the control plots

belonged to the genera Acidipila, Bryocella, Granulicella (Acidobacteria), Nostoc

(Cyanobacteria) and Acidiphilium (Alphaproteobacteria). ASVs more abundant under

warming belonged to the genera Allorhizobium-Neorhizobium-Pararhizobium-Rhizobium,

Nitrobacter, Sphingomonas (Alphaproteobacteria), Galbitalea (Actinobacteria), and

Rhizobacter (Gammaproteobacteria) (Fig. 3, Table S8).

Treatment effect on $16 \mathrm{~S}$ rRNA gene and nifH gene copy numbers and nitrogen fixation

rates

No significant difference was found in the 16S rRNA gene and nifH gene abundance between the control and warmed samples (Figs 1e-1f, Table S3). However, litter abundance negatively affected nifH gene abundance (pMCMC $=0.04$, Fig. 1f) and B. nana abundance tended to positively influence $16 \mathrm{~S}$ rRNA gene abundance (pMCMC $=0.072$, Fig. 1e).

We did not find any differences between $\mathrm{N}_{2}$-fixation rates (expressed as produced ethylene) in the control and warmed plots in June or August 2014 (Figs 1g-1h, Table S3). However, $\mathrm{N}_{2}$-fixation in control and warmed plots in August was significantly lower

Fig. 1h). 
Relationships between treatment, plant biomass, bacterial community structure and $\mathrm{N}_{2}-$

\section{1 fixation}

372 To explore the direct and indirect linkages between warming, B. nana and litter 373 abundance, bacterial community structure and $\mathrm{N}_{2}$-fixation, we constructed a structural equation model (SEM) (Fig. 4, Table S10). We found that warming was directly associated with changes in bacterial community structure and positively correlated with increased of $B$. nana abundance. The direct effect of $B$. nana was stronger than the direct effect of treatment on the bacterial community (-1.2 versus 0.79 standardized regression coefficients). Changes in the bacterial community structure were also indirectly associated with warming through variation in B. nana abundance.

The strongest positive effect detected was warming treatment on the bacterial community structure and the strongest negative effect was $B$. nana abundance on bacterial community structure (Fig. 4, Table S10).

Discussion

Mosses form an important $\mathrm{C}$ and $\mathrm{N}$ sink in high latitudes and their associated bacterial communities are, to a large extent, responsible for $\mathrm{N}$ inputs and organic matter decomposition in these environments. Elucidation of the effect of warming on moss-associated bacterial communities will help to understand how climate change affects $\mathrm{C}$ and $\mathrm{N}$ cycling driven by the bacterial component of mosses in high-latitude ecosystems. We assessed the effect of long-term (20 years) warming by open-top chambers (OTCs) on bacterial communities and $\mathrm{N}_{2}$-fixation associated with the moss $R$. lanuginosum at a tundra site in the highlands of Iceland. Overall, our results suggest that moss-associated bacterial communities are sensitive to long-term experimental warming and the associated plant community change, which 
however, appeared to be unaffected by warming and, consistent with this finding, no effect on

$\mathrm{N}_{2}$-fixation rates was observed. However, bacterial taxa that benefitted from the warming

treatment almost exclusively belonged to groups involved in $\mathrm{N}$-cycling, which might indicate

changes in $\mathrm{N}$ turnover and usage of this important nutrient for Arctic ecosystem productivity.

\section{Effect of warming on the moss-associated bacterial community structure}

The average temperature increase induced by the OTCs may seem small $\left(1-2^{\circ} \mathrm{C}\right)$, but a temperature increase in this range can affect microbial growth rate, respiration, $\mathrm{C}$ uptake and turnover (Walker et al., 2018). In addition, the effect of the OTC treatment is a long-term (20year) disturbance, which has shown a clear effect on the vegetation structure and biomass (Jonsdottir et al., 2005) and thereby also leads to indirect effects of warming on the microbial community.

The richness and Shannon diversity of the total and potentially metabolically active bacterial community were not significantly affected by 20 years of warming. These results contrast with our first hypothesis and with trends of decreasing richness and diversity in Sphagnum moss observed by Carrell et al. (2017) and by Kolton et al. (2019). R. lanuginosum has a much lower water holding capacity than Sphagnum (Elumeeva et al., 2011), a different physiology and grows in heathlands and therefore $R$. lanuginosum might react differently to warming. In addition, while our study describes the effect of 20 years warming in situ, those previous studies on Sphagnum were much shorter such as a four week laboratory (Kolton et al., 2019) and two years in situ experimental warming study (Carrell et al., 2019). Nevertheless, we found that warming altered the bacterial community structure, even though only a small part of the variation could be directly explained by the warming treatment. Warming correlated with an increase in shrub and litter abundance and a decrease in moss abundance, as already observed in the site after 3-4 years of warming (Jonsdottir et al., 2005). Indeed, a small part of the variation of the total bacterial community could be attributed to 
419 litter abundance, which also negatively affected the richness and diversity of the potentially

420 active bacterial community. In addition, the SEM showed that the bacterial community

421 structure was indirectly correlated with warming via changes in B. nana abundance, and

422 indirectly via the combined effect of $B$. nana and litter abundance. The effect of the increase

423 in $B$. nana abundance as result of warming was stronger than the direct effect of warming on

424 the bacterial community structure.

425 Warming-induced changes in environmental factors such as lower moss layer 426 thickness, higher soil organic matter content, lower soil moisture (Björnsdóttir, 2018;

427 Jonsdottir et al., 2005), or other not measured variables such as leaf nutrient content (Koyama

428 et al., 2018; Sayer et al., 2017; Vandenkoornhuyse et al., 2015) could also contribute to the

429 variation in bacterial communities between moss shoots.

430 We did not find an effect of warming on the 16S rRNA gene abundance, but $B$. nana

431 abundance was correlated with an increase in 16S rRNA gene abundance. However, as we are

432 not sure about the degree of bias towards chloroplast and mitochondrial DNA of the 16S

433 rRNA gene primers in our samples, we cannot conclude that the bacterial load is indeed

434 affected by B. nana abundance.

\section{Effect of warming on moss-associated bacterial taxa}

436 The total and potentially active bacterial community of $R$. lanuginosum was dominated by

437 Proteobacteria and Acidobacteria, whereas Actinobacteria, Cyanobacteria, Planctomycetes,

438 Bacteroidetes and Verrucomicrobia were present in lower abundances. In agreement with the

439 bacterial community composition of boreal moss species (Holland $\square$ Moritz et al., 2018) and

440 Sphagnum species (Bragina, Berg, et al., 2012), $R$. lanuginosum also showed a high

441 abundance of the Proteobacterial order Acetobacerales and the Acidobacterial order

442 Acidobacteriales. 
We analysed changes in relative abundances in several ways to better understand the

444 warming response of the moss bacterial community. This revealed changes in the relative

445 abundances of taxa on phylum, class, order and ASV levels. We hypothesized that the

446 warming-induced increase in labile B. nana litter (Jonsdottir et al., 2005) would lead to a

447 decrease in slow-growing, more oligotrophic taxa, while fast-growing copiotrophic taxa

448 would increase in relative abundance. Our data show indications for a decrease in the relative

449 abundance of oligotrophic taxa in response to warming, such as Acidobacteria (and more

450 specific ASVs of the genera Granulicella, Solibacter, Bryocella, Bryobacter and Acidipila)

451 (Dedysh \& Sinninghe Damsté, 2018; Fierer et al., 2007) and the Alphaproteobacterial genus

452 Acidiphilium (Hiraishi \& Imhoff, 2015). Acidobacteria often dominate tundra soils (Männistö

453 et al., 2013), especially environments with high concentrations of phenolic compounds, (for

454 instance in Sphagnum peat (Pankratov et al., 2011) and Empetrum heath (Gallet et al., 1999;

455 Männistö et al., 2013)). In shrub tundra dominated by B. nana and Salix species,

456 Proteobacteria dominate the soil bacterial community (Wallenstein et al., 2007). In our study,

457 the increase in the relative abundance of Proteobacteria (more specifically the genera

458 Rhizobacter, Nitrobacter and Rhizobium) associated with $R$. lanuginosum in the warmed plots

459 could thus be due to the increase in dwarf shrub biomass and labile litter, selecting for

460 copiotrophic taxa, such as Rhizobiales (Starke et al., 2016). Some oligotrophic taxa with

461 increased abundance in the warmed conditions such as Sphingomonadales and ASVs of the

462 Caulobacterales (Garrity et al., 2015) could be involved in degradation of more recalcitrant

463 plant organic matter (McGenity, 2019; Starke et al., 2016). Caulobacterales has for instance

464 been shown to be able to degrade lignin (Wilhelm et al., 2019), which can be found in high

465 concentrations in B. nana roots and leaves (McLaren et al., 2017). An increase in B. nana

466 litter likely increases the rate of C fluxes (Parker et al., 2018), and this may partly be due to a

467 shift towards faster growing copiotrophic bacterial taxa, at least in the moss layer. 
While the overall warming-induced changes in bacterial phylotypes for the total and the potentially active bacterial community were similar, we found that the total bacterial community reacted more strongly to warming than the potentially active bacterial community in terms of changes in relative abundance of the number of phyla, classes and ASVs. This difference may be explained by a difference in drivers for the total and potentially metabolically active bacteria, with changes in total bacterial community structure reflecting long-term drivers, while the active bacterial community may reflect short-term differences between OTC and controls (Y. Wang et al., 2020).

\section{Implications of warming for the moss bacterial community involved in $\mathrm{N}$-cycling}

Our results of the bacterial structure and composition revealed that warming induced changes in relative abundances of several taxa potentially involved in N-cycling. Here, it appears that these taxa involved in the first steps of the $\mathrm{N}$-cycle (entrance of new $\mathrm{N}$ through $\mathrm{N}_{2}$-fixation and production of nitrate from nitrite) are altered by warming. Although we did not explicitly target the $\mathrm{N}_{2}$-fixing or nitrifying community by sequencing in this study, we found indications for changes in the relative abundance of potentially $\mathrm{N}_{2}$-fixing and nitrifying taxa. In particular, the relative abundance of Cyanobacteria decreased. At the genus level, this was characterized by the lower abundance of the genus Nostoc. The vast majority of taxa that exclusively increased in abundance and had a higher potential metabolic activity under warming belong to groups capable of $\mathrm{N}_{2}$-fixation (Sphingomonas, Allorhizobium-

487 Neorhizobium-Pararhizobium-Rhizobium, Rhizobacter) and nitrification (Nitrobacter). However, neither nifH gene abundance nor $\mathrm{N}_{2}$-fixation rates were directly affected by nifH genes to warming in cold ecosystems (Salazar et al., 2019), where $\mathrm{N}_{2}$-fixation and

491 abundances of nifH genes are unresponsive and nitrification rates increase under warming 492 treatments. The apparent lack of response in $\mathrm{N}_{2}$-fixation rates to warming may be due to a 
493 combination of several direct and indirect effects of warming on $\mathrm{N}_{2}$-fixation rates

494 counterbalancing each other: the shift in the potentially $\mathrm{N}_{2}$-fixing community towards taxa

495 better adapted to the new environment and thereby compensating for the decrease in

496 Cyanobacteria in our study, the negative effect of drier conditions due to the warming

497 treatment (Rousk et al., 2018; Whiteley \& Gonzalez, 2016), the direct positive effect of

498 warming (Rousk \& Michelsen, 2017) and the negative effect of shading due to increasing

499 shrub cover (Sorensen et al., 2012) and the positive or negative effect of fertilization by shrub

500 litter (Rousk \& Michelsen, 2017; Sorensen \& Michelsen, 2011). The SEM however did not

501 indicate any links between the warming treatment, the bacterial community structure, litter

502 and $B$. nana abundance to nifH gene abundance or $\mathrm{N}_{2}$-fixation rates. One reason for this could

503 be that a degree of functional compensation occurs through the shift in the diazotrophic

504 community with warming. Nevertheless, the findings are supporting hypothesis 3 , and nifH

505 gene abundance was negatively affected by litter abundance and $\mathrm{N}_{2}$-fixation rates in August

506 were negatively affected by $B$. nana abundance, indicating the presence of indirect effects of

507 warming on $\mathrm{N}_{2}$-fixation. $\mathrm{N}_{2}$-fixation rates in August were also lower than in June in both

508 OTCs and control plots, maybe due to an increase of the effect of shading in August as

509 indicated by the effect of B. nana. It may also have been drier in August, or it could be due to

510 a seasonal shift in the $\mathrm{N}_{2}$-fixing bacterial community (Warshan et al., 2016).

511 Finally, it is important to note that $R$. lanuginosum biomass tends to decrease in the

512 warmed plots (Björnsdóttir, 2018; Jonsdottir et al., 2005, Table S2). Thus considering that in

513 our study $\mathrm{N}_{2}$-fixation rates are expressed per gram moss, warming would consequently lead to

514 a reduction of the total amount of $\mathrm{N}_{2}$ fixed per unit area in this tundra ecosystem.

515 Our study is among the first to assess the effect of long-term (20 years) experimental

516 warming with OTCs on the bacterial part of a moss microbiome. Our results showed no direct

517 response of $\mathrm{N}_{2}$-fixation rates and nifH gene abundance to warming. However, long-term 
518 warming led to changes in the bacterial community composition. On ASV level, these

519 changes were characterized by a decrease in the relative abundance of Cyanobacteria and an

520 increase in abundance and potential metabolic activity of non-cyanobacterial diazotrophs,

521 which may explain the lack of response of $\mathrm{N}_{2}$-fixation to warming. Our results also showed

522 that warming-induced changes in the surrounding vegetation structure can affect moss-

523 associated bacterial communities, thus underlining the importance of indirect effects of long-

524 term warming. The bacterial community associated with the moss might thus be sensitive to

525 future warming, with potential implications for $\mathrm{N}_{2}$-fixation rates, moss growth and C 526 sequestration. 


\section{Funding}

528

529

530

531

532

533

534

This work was supported by the MicroArctic Innovative Training Network grant supported by the European Commissions's Horizon 2020 Marie Sklodowska-Curie Actions program [grant number 675546] and the Energy Research Fund [grants to ISJ, numbers 082013, NÝR-09-2014].

\section{Acknowledgements}

We thank Dr. Ólafur S. Andrésson, Dr. Marie-Charlotte Nilsson, and Dr. Matthias Zielke for help and advice on the RNA and DNA extractions and the ARAs. We would also like to thank Quentin J.B. Horta-Lacueva for advice on the statistical analysis.

\section{Competing Interests}

The authors declare that the research was conducted in the absence of any conflict of interest.

\section{Author contributions}

IJK, AJRC, ISJ and OV designed the study. IJK, AJRC and CK performed the research. IJK analysed the data and wrote the paper with input from AJRC, CK, DW, ADJ, ISJ and OV.

\section{Data availability}

Raw sequences are available in the European Nucleotide Archive under accession number PRJEB40635.

\section{References}

Anderson, M. J. (2001). A new method for non-parametric multivariate analysis of variance. Austral Ecology, 26(1), 32-46.

Berg, A., Danielsson, Å., \& Svensson, B. H. (2013). Transfer of fixed-N from N2-fixing cyanobacteria associated with the moss Sphagnum riparium results in enhanced 
growth of the moss. Plant and Soil, 362(1-2), 271-278. https://doi.org/10.1007/s11104-012-1278-4

Bjarnason, Ágúst H. 1991. Vegetation on Lava Fields in the Hekla Area, Iceland. Acta Phytogeographica Suecica 77. Uppsala $\square$ : Stockholm: Svenska växtgeografiska sällskapet $\square$; Almqvist \& Wiksell International.

Bjorkman, A. D., García Criado, M., Myers-Smith, I. H., Ravolainen, V., Jónsdóttir, I. S., Westergaard, K. B., Lawler, J. P., Aronsson, M., Bennett, B., Gardfjell, H., Heiðmarsson, S., Stewart, L., \& Normand, S. (2020). Status and trends in Arctic vegetation: Evidence from experimental warming and long-term monitoring. Ambio, 49(3), 678-692. https://doi.org/10.1007/s13280-019-01161-6

Björnsdóttir, K. (2018). Decomposition responses to climate warming and sheep grazing in the high and sub-Arctic (p. 85) [Master thesis]. University of Iceland.

Blazewicz, S. J., Barnard, R. L., Daly, R. A., \& Firestone, M. K. (2013). Evaluating rRNA as an indicator of microbial activity in environmental communities: Limitations and uses. The ISME Journal, 7, 2061-2068.

Bragina, A., Berg, C., Cardinale, M., Shcherbakov, A., Chebotar, V., \& Berg, G. (2012). Sphagnum mosses harbour highly specific bacterial diversity during their whole lifecycle. The ISME Journal, 6(4), 802-813. https://doi.org/10.1038/ismej.2011.151

Bragina, A., Maier, S., Berg, C., Müller, H., Chobot, V., Hadacek, F., \& Berg, G. (2012). Similar Diversity of Alphaproteobacteria and Nitrogenase Gene Amplicons on Two Related Sphagnum Mosses. Frontiers in Microbiology, 2(275). https://doi.org/10.3389/fmicb.2011.00275

Callahan, B. J., McMurdie, P. J., \& Holmes, S. P. (2017). Exact sequence variants should replace operational taxonomic units in marker-gene data analysis. The ISME Journal, 11, 2639-2643. https://doi.org/10.1038/ismej.2017.119 
574 Callahan, B. J., McMurdie, P. J., Rosen, M. J., Han, A. W., Johnson, A. J. A., \& Holmes, S.

575 P. (2016). DADA2: High-resolution sample inference from Illumina amplicon data.

$576 \quad$ Nature Methods, 13(7), 581-583. https://doi.org/10.1038/nmeth.3869

577 Carrell, A. A., Kolton, M., Glass, J. B., Pelletier, D. A., Warren, M. J., Kostka, J. E., Iversen,

578 C. M., Hanson, P. J., \& Weston, D. J. (2019). Experimental warming alters the community composition, diversity, and $\mathrm{N}_{2}$ fixation activity of peat moss ( Sphagnum fallax ) microbiomes. Global Change Biology, 25(9), 2993-3004. https://doi.org/10.1111/gcb.14715

Chen, K.-H., Liao, H.-L., Bellenger, J.-P., \& Lutzoni, F. (2019). Differential gene expression associated with fungal trophic shifts along the senescence gradient of the moss Dicranum scoparium. Environmental Microbiology, 21(7), 2273-2289. https://doi.org/10.1111/1462-2920.14605

Cornelissen, J. H. C., Lang, S. I., Soudzilovskaia, N. A., \& During, H. J. (2007). Comparative

De Caceres, M., \& Legendre, P. (2009). Associations between species and groups of sites: Indices and statistical inference. Ecology, 90(12), 3566-3574.

DeLuca, T. H., Zackrisson, O., Nilsson, M.-C., \& Sellstedt, A. (2002). Quantifying nitrogen- 
598 Deslippe, J. R., Egger, K. N., \& Henry, G. H. R. (2005). Impacts of warming and fertilization 599 on nitrogen-fixing microbial communities in the Canadian High Arctic. FEMS $600 \quad$ Microbiology Ecology, 53(1), 41-50. https://doi.org/10.1016/j.femsec.2004.12.002

601

602

603

604

605

606

607

608

609

610

611

612

613

614

615

616

617

618

619

620

621

622

Deslippe, J. R., Hartmann, M., Simard, S. W., \& Mohn, W. W. (2012). Long-term warming alters the composition of Arctic soil microbial communities. FEMS Microbiology Ecology, 82(2), 303-315. https://doi.org/10.1111/j.1574-6941.2012.01350.x

Elbert, W., Weber, B., Burrows, S., Steinkamp, J., Büdel, B., Andreae, M. O., \& Pöschl, U. (2012). Contribution of cryptogamic covers to the global cycles of carbon and nitrogen. Nature Geoscience, 5(7), 459-462. https://doi.org/10.1038/ngeo1486

Elumeeva, T. G., Soudzilovskaia, N. A., During, H. J., \& Cornelissen, J. H. C. (2011). The importance of colony structure versus shoot morphology for the water balance of 22 subarctic bryophyte species. Journal of Vegetation Science, 22(1), 152-164. https://doi.org/10.1111/j.1654-1103.2010.01237.x

Fierer, N., Bradford, M. A., \& Jackson, R. B. (2007). TOWARD AN ECOLOGICAL CLASSIFICATION OF SOIL BACTERIA. Ecology, 88(6), 1354-1364. https://doi.org/10.1890/05-1839

Gallet, C., Nilsson, M.-C., \& Zackrisson, O. (1999). Phenolic metabolites of ecological significance in Empetrum hermaphroditum leaves and associated humus. Plant and Soil, 1(9), 9.

Garrity, G. M., Bell, J. A., \& Lilburn, T. (2015). Caulobacteraceae. In W. B. Whitman, F. Rainey, P. Kämpfer, M. Trujillo, J. Chun, P. DeVos, B. Hedlund, \& S. Dedysh (Eds.), Bergey's Manual of Systematics of Archaea and Bacteria (pp. 1-1). John Wiley \& Sons, Ltd. https://doi.org/10.1002/9781118960608.fbm00162

Gentili, F., Nilsson, M.-C., Zackrisson, O., DeLuca, T. H., \& Sellstedt, A. (2005). Physiological and molecular diversity of feather moss associative N2-fixing 
cyanobacteria. Journal of Experimental Botany, 56(422), 3121-3127. https://doi.org/10.1093/jxb/eri309

Hadfield, J. D. (2010). MCMC Methods for Multi-Response Generalized Linear Mixed Models: The MCMCglmm R Package. Journal of Statistical Software, 33(1), 1-22. https://doi.org/10.18637/jss.v033.i02

Henry, G. H. R., \& Molau, U. (1997). Tundra plants and climate change: The International Tundra Experiment (ITEX). Global Change Biology, 3(S1), 1-9. https://doi.org/10.1111/j.1365-2486.1997.gcb132.x

Hiraishi, A., \& Imhoff, J. F. (2015). Acidiphilium. In W. B. Whitman, F. Rainey, P. Kämpfer, M. Trujillo, J. Chun, P. DeVos, B. Hedlund, \& S. Dedysh (Eds.), Bergey's Manual of Systematics of Archaea and Bacteria (pp. 1-14). John Wiley \& Sons, Ltd. https://doi.org/10.1002/9781118960608.gbm00877

Ho, A., Angel, R., Veraart, A. J., Daebeler, A., Jia, Z., Kim, S. Y., Kerckhof, F.-M., Boon, N., \& Bodelier, P. L. E. (2016). Biotic Interactions in Microbial Communities as Modulators of Biogeochemical Processes: Methanotrophy as a Model System. Frontiers in Microbiology, 7. https://doi.org/10.3389/fmicb.2016.01285

Holland $\square$ Moritz, H., Stuart, J., Lewis, L. R., Miller, S., Mack, M. C., McDaniel, S. F., \& Fierer, N. (2018). Novel bacterial lineages associated with boreal moss species. Environmental Microbiology, 20(7), 2625-2638. https://doi.org/10.1111/14622920.14288

Hollister, R. D., \& Webber, P. J. (2000). Biotic validation of small open-top chambers in a tundra ecosystem. Global Change Biology, 6(7), 835-842. https://doi.org/10.1046/j.1365-2486.2000.00363.x 
646 Hooper, D., Coughlan, J., \& Mullen, M. (2008). Structural Equation Modelling: Guidelines

647 for Determining Model Fit. Electronic Journal of Business Research Methods, 6(1), $648 \quad 53-60$.

649 Houlton, B. Z., Wang, Y.-P., Vitousek, P. M., \& Field, C. B. (2008). A unifying framework

650 for dinitrogen fixation in the terrestrial biosphere. Nature, 454(7202), 327-330.

$651 \quad$ https://doi.org/10.1038/nature07028

652 Ingimundardóttir, G. V., Weibull, H., \& Cronberg, N. (2014). Bryophyte colonization history

653 of the virgin volcanic island Surtsey, Iceland. Biogeosciences, 11(16), 4415-4427.

654 https://doi.org/10.5194/bg-11-4415-2014

655 Ininbergs, K., Bay, G., Rasmussen, U., Wardle, D. A., \& Nilsson, M.-C. (2011). Composition

656 and diversity of nifH genes of nitrogen-fixing cyanobacteria associated with boreal

657 forest feather mosses. The New Phytologist, 192(2), 507-517.

$658 \quad$ https://doi.org/10.1111/j.1469-8137.2011.03809.x

659 IPCC. (2019). Special Report on the Ocean and Cryosphere in a Changing Climate (SROCC)

660 (p. 1170). https://report.ipcc.ch/srocc/pdf/SROCC_FinalDraft_FullReport.pdf

Jean, M., Holland $\square$ Moritz, H., Melvin, A. M., Johnstone, J. F., \& Mack, M. C. (2020).

662

Experimental assessment of tree canopy and leaf litter controls on the microbiome and

663 nitrogen fixation rates of two boreal mosses. New Phytologist, $n / a(\mathrm{n} / \mathrm{a})$.

Jonsdottir, I. S., Callaghan, T. V., \& Lee, J. A. (1995). Fate of added nitrogen in a moss-sedge Arctic community and effects of increased nitrogen deposition. Science of The Total Environment, 160-161, 677-685. https://doi.org/10.1016/0048-9697(95)04402-M 
671 Kassambara, A. (2020). ggpubr: “ggplot2” Based Publication Ready Plots (0.2.5) [Computer

672 software]. https://CRAN.R-project.org/package=ggpubr

673 Klindworth, A., Pruesse, E., Schweer, T., Peplies, J., Quast, C., Horn, M., \& Glöckner, F. O.

674

675

676

677

678

679

680

681

682

683

684

685

686

687

688

689

690

691

692

693
(2013). Evaluation of general 16S ribosomal RNA gene PCR primers for classical and next-generation sequencing-based diversity studies. Nucleic Acids Research, 41(1), e1. https://doi.org/10.1093/nar/gks808

Kolton, M., Marks, A., Wilson, R. M., Chanton, J. P., \& Kostka, J. E. (2019). Impact of Warming on Greenhouse Gas Production and Microbial Diversity in Anoxic Peat From a Sphagnum-Dominated Bog (Grand Rapids, Minnesota, United States). Frontiers in Microbiology, 10(870). https://doi.org/10.3389/fmicb.2019.00870

Köppen, W. P. (1931). Grundriss der Klimakunde. Walter de Gruyter \& Co. https://agris.fao.org/agris-search/search.do?recordID=US201300361310

Kostka, J. E., Weston, D. J., Glass, J. B., Lilleskov, E. A., Shaw, A. J., \& Turetsky, M. R. (2016). The Sphagnum microbiome: New insights from an ancient plant lineage. New Phytologist, 211(1), 57-64. https://doi.org/10.1111/nph.13993

Koyama, A., Steinweg, J. M., Haddix, M. L., Dukes, J. S., \& Wallenstein, M. D. (2018). Soil bacterial community responses to altered precipitation and temperature regimes in an old field grassland are mediated by plants. FEMS Microbiology Ecology, 94(1), fix 156. https://doi.org/10.1093/femsec/fix156

Kulichevskaya, I. S., Belova, S. E., Kevbrin, V. V., Dedysh, S. N., \& Zavarzin, G. A. (2007). Analysis of the bacterial community developing in the course of Sphagnum moss decomposition. Microbiology, 76(5), 621-629. https://doi.org/10.1134/S0026261707050165 
694 Lindo, Z., \& Gonzalez, A. (2010). The Bryosphere: An Integral and Influential Component of

695 the Earth's Biosphere. Ecosystems, 13(4), 612-627. https://doi.org/10.1007/s10021-

696 010-9336-3

697

Lindo, Z., Nilsson, M.-C., \& Gundale, M. J. (2013). Bryophyte-cyanobacteria associations as regulators of the northern latitude carbon balance in response to global change. Global Change Biology, 19(7), 2022-2035. https://doi.org/10.1111/gcb.12175

Longton, R. (1992). The role of bryophytes and lichens in terrestrial ecosystems. In J. Bates \& Farmer, AM (Eds.), Bryophytes and lichens in a changing environment (pp. 32-76). University Press. https://www.esf.edu/efb/Kimmerer/mossecology/reserve/Role_of_bryophytes_and_lic

McLaren, J. R., Buckeridge, K. M., van de Weg, M. J., Shaver, G. R., Schimel, J. P., \& above- and belowground litter decomposition. Ecology, 98(5), 1361-1376. https://doi.org/10.1002/ecy.1790 
McMurdie, P. J., \& Holmes, S. (2013). phyloseq: An R Package for Reproducible Interactive Analysis and Graphics of Microbiome Census Data. PLOS ONE, 8(4), e61217. https://doi.org/10.1371/journal.pone.0061217

Molau, U., \& Mølgaard, P. (1996). ITEX manual (2nd ed.). Danish Polar Center.

Myers-Smith, I. H., Forbes, B. C., Wilmking, M., Hallinger, M., Lantz, T., Blok, D., Tape, K. D., Macias-Fauria, M., Sass-Klaassen, U., Lévesque, E., Boudreau, S., Ropars, P., Hermanutz, L., Trant, A., Collier, L. S., Weijers, S., Rozema, J., Rayback, S. A., Schmidt, N. M., ... Hik, D. S. (2011). Shrub expansion in tundra ecosystems: Dynamics, impacts and research priorities. Environmental Research Letters, 6(4), 045509. https://doi.org/10.1088/1748-9326/6/4/045509

Myers $\square$ Smith, I. H., Grabowski, M. M., Thomas, H. J. D., Angers $\square$ Blondin, S., Daskalova, G. N., Bjorkman, A. D., Cunliffe, A. M., Assmann, J. J., Boyle, J. S., McLeod, E., McLeod, S., Joe, R., Lennie, P., Arey, D., Gordon, R. R., \& Eckert, C. D. (2019). Eighteen years of ecological monitoring reveals multiple lines of evidence for tundra vegetation change. Ecological Monographs, 89(2), e01351. https://doi.org/10.1002/ecm.1351

Oksanen, J., Blanchet, F. G., Kindt, R., Legendre, P., Minchin, P. R., O’hara, R. B., Simpson, G. L., Solymos, P., Stevens, M. H. H., \& Wagner, H. (2013). Package 'vegan.' Community Ecology Package, Version, 2(9), 296.

Pankratov, T. A., Ivanova, A. O., Dedysh, S. N., \& Liesack, W. (2011). Bacterial populations and environmental factors controlling cellulose degradation in an acidic Sphagnum peat. Environmental Microbiology, 13(7), 1800-1814. https://doi.org/10.1111/j.14622920.2011.02491.x

Parker, T. C., Sanderman, J., Holden, R. D., Blume $\square$ Werry, G., Sjögersten, S., Large, D., Castro $\square$ Díaz, M., Street, L. E., Subke, J.-A., \& Wookey, P. A. (2018). Exploring 
drivers of litter decomposition in a greening Arctic: Results from a transplant experiment across a treeline. Ecology, 99(10), 2284-2294. https://doi.org/10.1002/ecy.2442

Paulson, J. N., Stine, O. C., Bravo, H. C., \& Pop, M. (2013). Differential abundance analysis for microbial marker-gene surveys. Nature Methods, 10(12), 1200-1202. https://doi.org/10.1038/nmeth.2658

Poly, F., Monrozier, L. J., \& Bally, R. (2001). Improvement in the RFLP procedure for studying the diversity of nifH genes in communities of nitrogen fixers in soil. Research in Microbiology, 152(1), 95-103. https://doi.org/10.1016/S09232508(00)01172-4

Porada, P., Weber, B., Elbert, W., Pöschl, U., \& Kleidon, A. (2013). Estimating global carbon uptake by lichens and bryophytes with a process-based model. Biogeosciences, 10(11), 6989-7033. https://doi.org/10.5194/bg-10-6989-2013

Quast, C., Pruesse, E., Yilmaz, P., Gerken, J., Schweer, T., Yarza, P., Peplies, J., \& Glöckner, F. O. (2013). The SILVA ribosomal RNA gene database project: Improved data processing and web-based tools. Nucleic Acids Research, 41(D1), D590-D596. https://doi.org/10.1093/nar/gks1219

Raymond, J. A. (2016). Dependence on epiphytic bacteria for freezing protection in an Antarctic moss, Bryum argenteum. Environmental Microbiology Reports, 8(1), 14-19. https://doi.org/10.1111/1758-2229.12337

Rousk, K., Jones, D. L., \& DeLuca, T. H. (2013). Moss-cyanobacteria associations as biogenic sources of nitrogen in boreal forest ecosystems. Frontiers in Microbiology, 4(150). https://doi.org/10.3389/fmicb.2013.00150 
767 Rousk, K., Jones, D. L., \& DeLuca, T. H. (2014). The resilience of nitrogen fixation in feather moss (Pleurozium schreberi)-cyanobacteria associations after a drying and rewetting cycle. Plant and Soil, 377(1-2), 159-167. https://doi.org/10.1007/s11104-013-1984-6

Rousk, K., \& Michelsen, A. (2017). Ecosystem nitrogen fixation throughout the snow-free period in subarctic tundra: Effects of willow and birch litter addition and warming. Global Change Biology, 23(4), 1552-1563. https://doi.org/10.1111/gcb.13418

Rousk, K., Sorensen, P. L., Lett, S., \& Michelsen, A. (2015). Across-Habitat Comparison of Diazotroph Activity in the Subarctic. Microbial Ecology, 69(4), 778-787. https://doi.org/10.1007/s00248-014-0534-y

Rousk, K., Sorensen, P. L., \& Michelsen, A. (2017). Nitrogen fixation in the High Arctic: A source of 'new' nitrogen? Biogeochemistry, 136(2), 213-222. https://doi.org/10.1007/s10533-017-0393-y

Rousk, K., Sorensen, P. L., \& Michelsen, A. (2018). What drives biological nitrogen fixation in high arctic tundra: Moisture or temperature? Ecosphere, 9(2), e02117. https://doi.org/10.1002/ecs2.2117

Salazar, A., Rousk, K., Jónsdóttir, I. S., Bellenger, J., \& Andrésson, Ó. S. (2019). Faster nitrogen cycling and more fungal and root biomass in cold ecosystems under experimental warming: A meta $\square$ analysis. Ecology. https://doi.org/10.1002/ecy.2938

Sayer, E. J., Oliver, A. E., Fridley, J. D., Askew, A. P., Mills, R. T. E., \& Grime, J. P. (2017). Links between soil microbial communities and plant traits in a species $\square$ rich grassland under long $\square$ term climate change. Ecology and Evolution, 7(3), 855-862. https://doi.org/10.1002/ece3.2700

Sorensen, P. L., Lett, S., \& Michelsen, A. (2012). Moss-specific changes in nitrogen fixation following two decades of warming, shading, and fertilizer addition. Plant Ecology, 213(4), 695-706. https://doi.org/10.1007/s11258-012-0034-4 
792 Sorensen, P. L., \& Michelsen, A. (2011). Long-term warming and litter addition affects

793 nitrogen fixation in a subarctic heath. Global Change Biology, 17(1), 528-537.

794 https://doi.org/10.1111/j.1365-2486.2010.02234.x

795

796

Starke, R., Kermer, R., Ullmann-Zeunert, L., Baldwin, I. T., Seifert, J., Bastida, F., von Bergen, M., \& Jehmlich, N. (2016). Bacteria dominate the short-term assimilation of plant-derived N in soil. Soil Biology and Biochemistry, 96, 30-38. https://doi.org/10.1016/j.soilbio.2016.01.009

Stewart, K. J., Coxson, D., \& Grogan, P. (2011). Nitrogen Inputs by Associative Cyanobacteria across a Low Arctic Tundra Landscape. Arctic, Antarctic, and Alpine Research, 43(2), 267-278. https://doi.org/10.1657/1938-4246-43.2.267

Stewart, K. J., Grogan, P., Coxson, D. S., \& Siciliano, S. D. (2014). Topography as a key factor driving atmospheric nitrogen exchanges in arctic terrestrial ecosystems. Soil Biology and Biochemistry, 70, 96-112. https://doi.org/10.1016/j.soilbio.2013.12.005

Stewart, K. J., Lamb, E. G., Coxson, D. S., \& Siciliano, S. D. (2011). Bryophytecyanobacterial associations as a key factor in N2-fixation across the Canadian Arctic. Plant and Soil, 344(1-2), 335-346. https://doi.org/10.1007/s11104-011-0750-x

Tallis, J. H. (1958). Studies in the Biology and Ecology of Rhacomitrium Lanuginosum Brid.: I. Distribution and Ecology. Journal of Ecology, 46(2), 271-288. JSTOR. https://doi.org/10.2307/2257395

Tallis, J. H. (1995). Climate and Erosion Signals in British Blanket Peats: The Significance of Racomitrium Lanuginosum Remains. Journal of Ecology, 83(6), 1021-1030. JSTOR. https://doi.org/10.2307/2261183

Tang, J. Y., Ma, J., Li, X. D., \& Li, Y. H. (2016). Illumina sequencing-based community analysis of bacteria associated with different bryophytes collected from Tibet, China. BMC Microbiology, 16(276). https://doi.org/10.1186/s12866-016-0892-3 
817 Turetsky, M. R. (2003). The Role of Bryophytes in Carbon and Nitrogen Cycling. The Bryologist, 106(3), 395-409.

Turetsky, M. R., Bond-Lamberty, B., Euskirchen, E., Talbot, J., Frolking, S., McGuire, A. D., \& Tuittila, E.-S. (2012). The resilience and functional role of moss in boreal and arctic ecosystems: Tansley review. New Phytologist, 196(1), 49-67. Environmental Microbiology, 73(16), 5261-5267. https://doi.org/10.1111/j.1469-8137.2012.04254.x

Van der Putten, W. H. (2012). Climate Change, Aboveground-Belowground Interactions, and Species’ Range Shifts. Annual Review of Ecology, Evolution, and Systematics, 43(1), 365-383. https://doi.org/10.1146/annurev-ecolsys-110411-160423

Vandenkoornhuyse, P., Quaiser, A., Duhamel, M., Van, A. L., \& Dufresne, A. (2015). The importance of the microbiome of the plant holobiont. New Phytologist, 206(4), 11961206. https://doi.org/10.1111/nph.13312

Walker, T. W. N., Kaiser, C., Strasser, F., Herbold, C. W., Leblans, N. I. W., Woebken, D., Janssens, I. A., Sigurdsson, B. D., \& Richter, A. (2018). Microbial temperature sensitivity and biomass change explain soil carbon loss with warming. Nature Climate Change, 8(10), 885-889. https://doi.org/10.1038/s41558-018-0259-x

Wallenstein, M. D., McMahon, S., \& Schimel, J. (2007). Bacterial and fungal community structure in Arctic tundra tussock and shrub soils. FEMS Microbiology Ecology, 59(2), 428-435. https://doi.org/10.1111/j.1574-6941.2006.00260.x

Wang, Q., Garrity, G. M., Tiedje, J. M., \& Cole, J. R. (2007). Naive Bayesian classifier for rapid assignment of rRNA sequences into the new bacterial taxonomy. Applied and https://doi.org/10.1128/AEM.00062-07 
840 Wang, Y., Ma, A., Liu, G., Ma, J., Wei, J., Zhou, H., Brandt, K. K., \& Zhuang, G. (2020).

841

842

843

844
Potential feedback mediated by soil microbiome response to warming in a glacier forefield. Global Change Biology, 26(2), 697-708. https://doi.org/10.1111/gcb.14936

Warshan, D., Bay, G., Nahar, N., Wardle, D. A., Nilsson, M.-C., \& Rasmussen, U. (2016). Seasonal variation in nifH abundance and expression of cyanobacterial communities associated with boreal feather mosses. The ISME Journal, 10(9), 2198.

Warshan, D., Espinoza, J. L., Stuart, R. K., Richter, R. A., Kim, S.-Y., Shapiro, N., Woyke, T., C Kyrpides, N., Barry, K., Singan, V., Lindquist, E., Ansong, C., Purvine, S. O., M Brewer, H., Weyman, P. D., Dupont, C. L., \& Rasmussen, U. (2017). Feathermoss and epiphytic Nostoc cooperate differently: Expanding the spectrum of plantcyanobacteria symbiosis. The ISME Journal, 11(12), 2821-2833. https://doi.org/10.1038/ismej.2017.134

Whiteley, J. A., \& Gonzalez, A. (2016). Biotic nitrogen fixation in the bryosphere is inhibited more by drought than warming. Oecologia, 181(4), 1243-1258. https://doi.org/10.1007/s00442-016-3601-X

Wilhelm, R. C., Singh, R., Eltis, L. D., \& Mohn, W. W. (2019). Bacterial contributions to delignification and lignocellulose degradation in forest soils with metagenomic and quantitative stable isotope probing. The ISME Journal, 13(2), 413-429. https://doi.org/10.1038/s41396-018-0279-6

Wookey, P. A., Aerts, R., Bardgett, R. D., Baptist, F., Bråthen, K. A., Cornelissen, J. H. C., Gough, L., Hartley, I. P., Hopkins, D. W., Lavorel, S., \& Shaver, G. R. (2009). Ecosystem feedbacks and cascade processes: Understanding their role in the responses of Arctic and alpine ecosystems to environmental change. Global Change Biology, 15(5), 1153-1172. https://doi.org/10.1111/j.1365-2486.2008.01801.x 
864 Wu, C., Wei, X., Hu, Z., Liu, Y., Hu, Y., Qin, H., Chen, X., Wu, J., Ge, T., Zhran, M., \& Su,

865 Y. (2020). Diazotrophic Community Variation Underlies Differences in Nitrogen

866 Fixation Potential in Paddy Soils Across a Climatic Gradient in China. Microbial

867 Ecology. https://doi.org/10.1007/s00248-020-01591-w

868 Zackrisson, O., DeLuca, T. H., Nilsson, M.-C., Sellstedt, A., \& Berglund, L. M. (2004).

869 NITROGEN FIXATION INCREASES WITH SUCCESSIONAL AGE IN BOREAL

$870 \quad$ FORESTS. Ecology, 85(12), 3327-3334. https://doi.org/10.1890/04-0461

871 Zielke, M., Solheim, B., Spjelkavik, S., \& Olsen, R. A. (2005). Nitrogen fixation in the high

872 arctic: Role of vegetation and environmental conditions. Arctic, Antarctic, and Alpine

$873 \quad$ Research, 37(3), 372-378.

874

875

876

877 
a

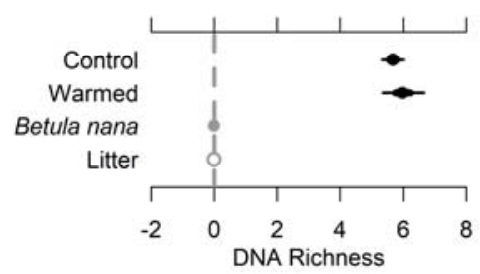

c

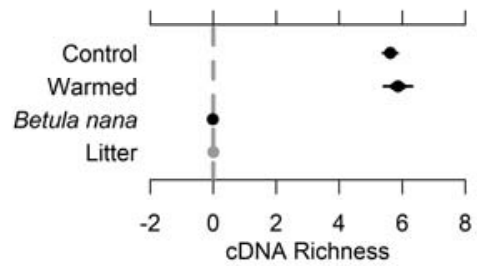

e

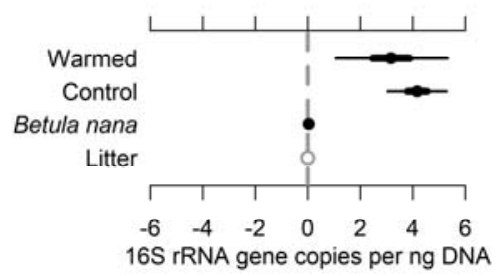

g

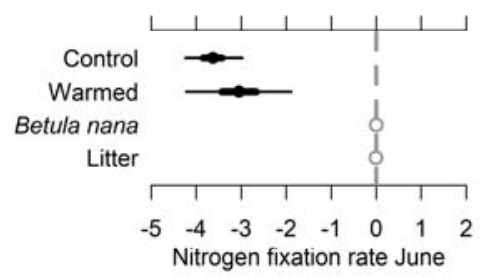

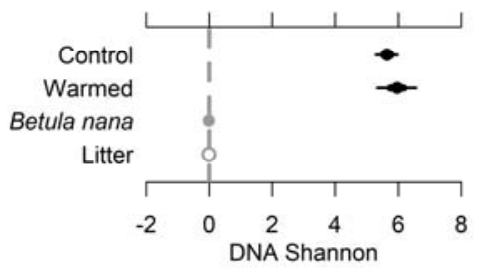

d

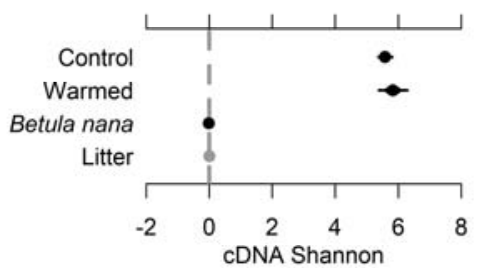

f

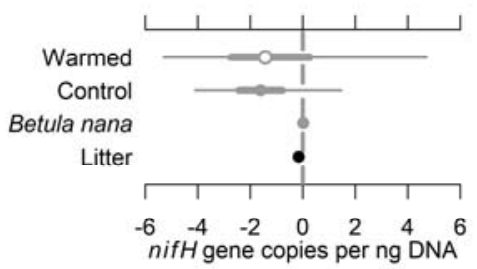

h

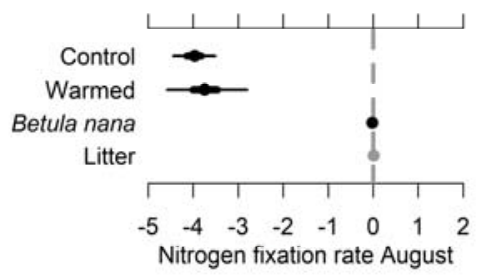

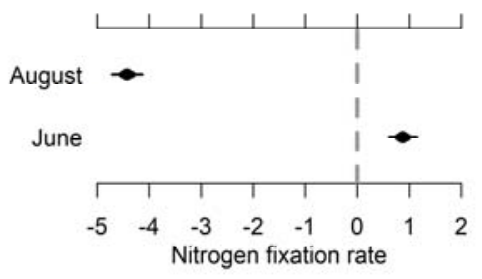

Figure 1 Fixed effect structure of the linear mixed-effect models testing the effect of treatment (warmed and control), Betula nana abundance and litter abundance on a) DNAbased richness and b) Shannon diversity, c) cDNA-based richness and d) Shannon diversity, e) 16 rRNA gene abundance, f) nifH gene abundance, $\mathrm{N}_{2}$-fixation rate g) in June, h) in August and i) fixed effect structure of the linear mixed-effect model testing the difference between $\mathrm{N}_{2}$-fixation rates in June and August. Non-overlapping 95\% High Posterior Density Credible Interval $(95 \% \mathrm{CrI})$ are used to detect significant differences between effects. Parameters with $50 \% \mathrm{CrI}$ overlapping 0 are indicated by open circles. Parameters with $50 \% \mathrm{CrI}$ not overlapping 0 , but with $95 \% \mathrm{CrI}$ overlapping 0 are indicated by closed black circles. Thick lines represent $50 \% \mathrm{CrI}$ and thin lines represent $95 \% \mathrm{CrI}$. 
bioRxiv preprint doi: https://doi org/10.1101/838581; this version posted March 2, 2021. The copyright holder for this preprint (which was not certified by peer review) is the author/funder, who has granted bioRxiv a license to display the preprint in perpetuity. It is made available under aCC-BY-NC-ND 4.0 International license.

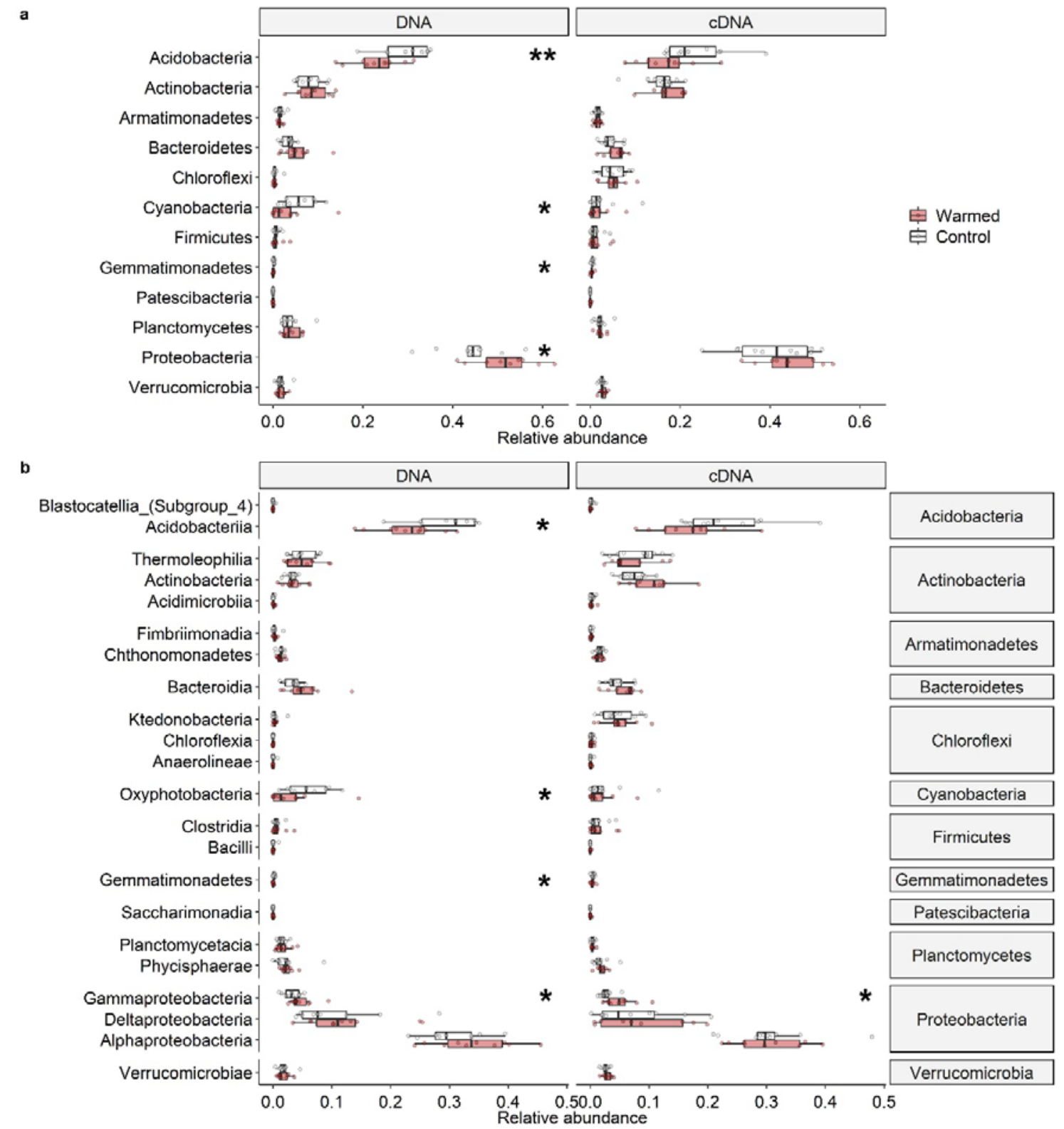

892 Figure 2 Boxplots of the relative abundances of (A) phyla and (B) classes in DNA and cDNA 893 based bacterial communities associated with the moss $R$. lanuginosum. Boxplots represent 894 minimum values, first quartiles, medians, third quartiles and maximum values. Significance 895 levels $(*<0.05, * *<0.01)$ are based on Wilcoxon rank sum tests. 
bioRxiv preprint doi: https://doi org/10.1101/838581; this version posted March 2 2021. The copyright holder for this preprint (which was not certified by peer review) is the author/funder, who has granted bioRxiv a license to display the preprint in perpetuity. It is made available under aCC-BY-NC-ND 4.0 International license.

897

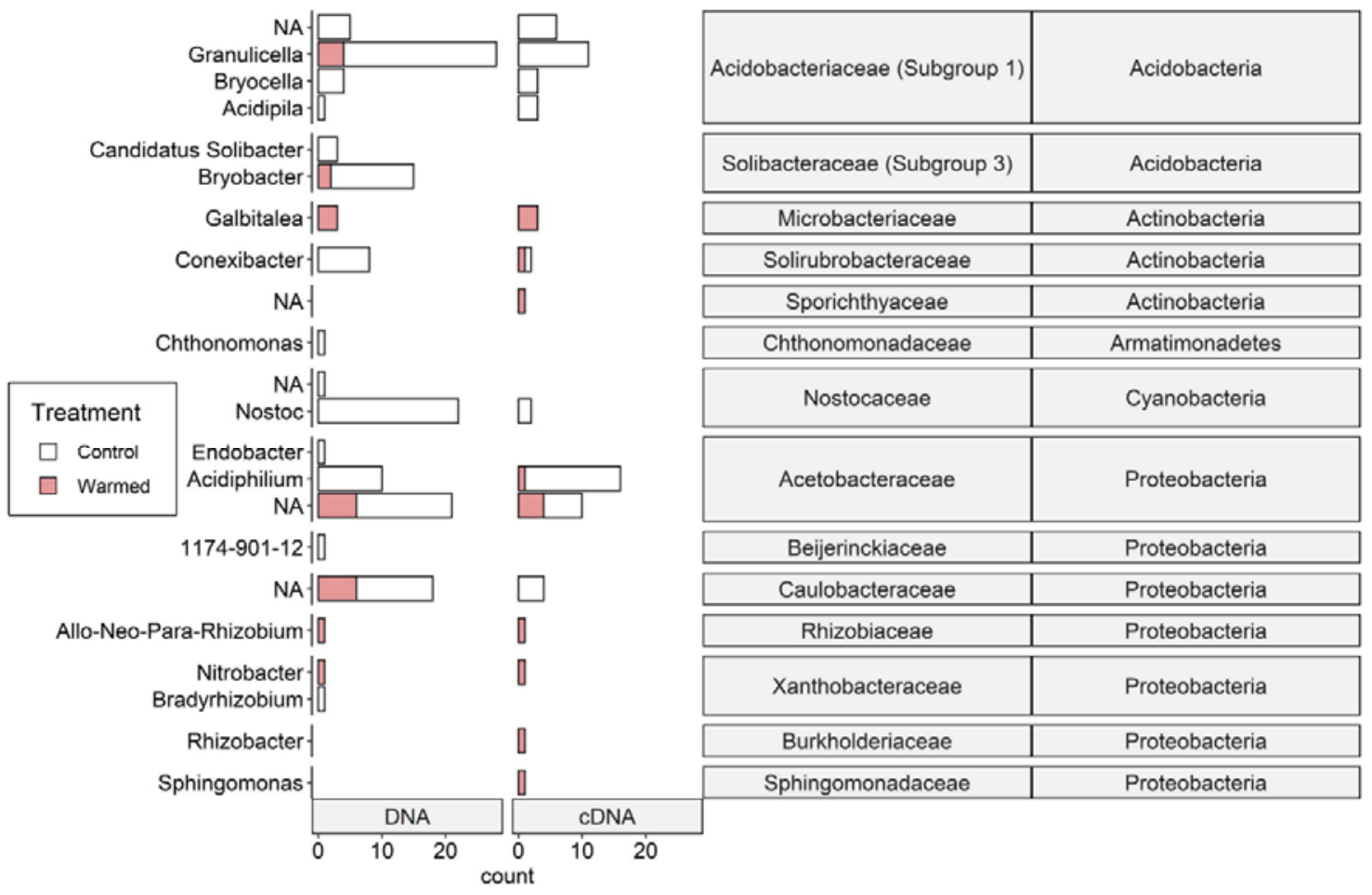

898 Figure 3 Number of ASVs (amplicon sequence variants) per genus sensitive to warming for 899 DNA and cDNA based bacterial communities associated with the moss $R$. lanuginosum.

900 Sensitivity was determined by differential abundance analysis (DESeq2) and indicator species 901 analysis. ASVs not assigned to genus level are labelled 'NA' and 'Allo-Neo-Para-Rhizobium' 902 refers to 'Allorhizobium-Neorhizobium-Pararhizobium-Rhizobium'. 


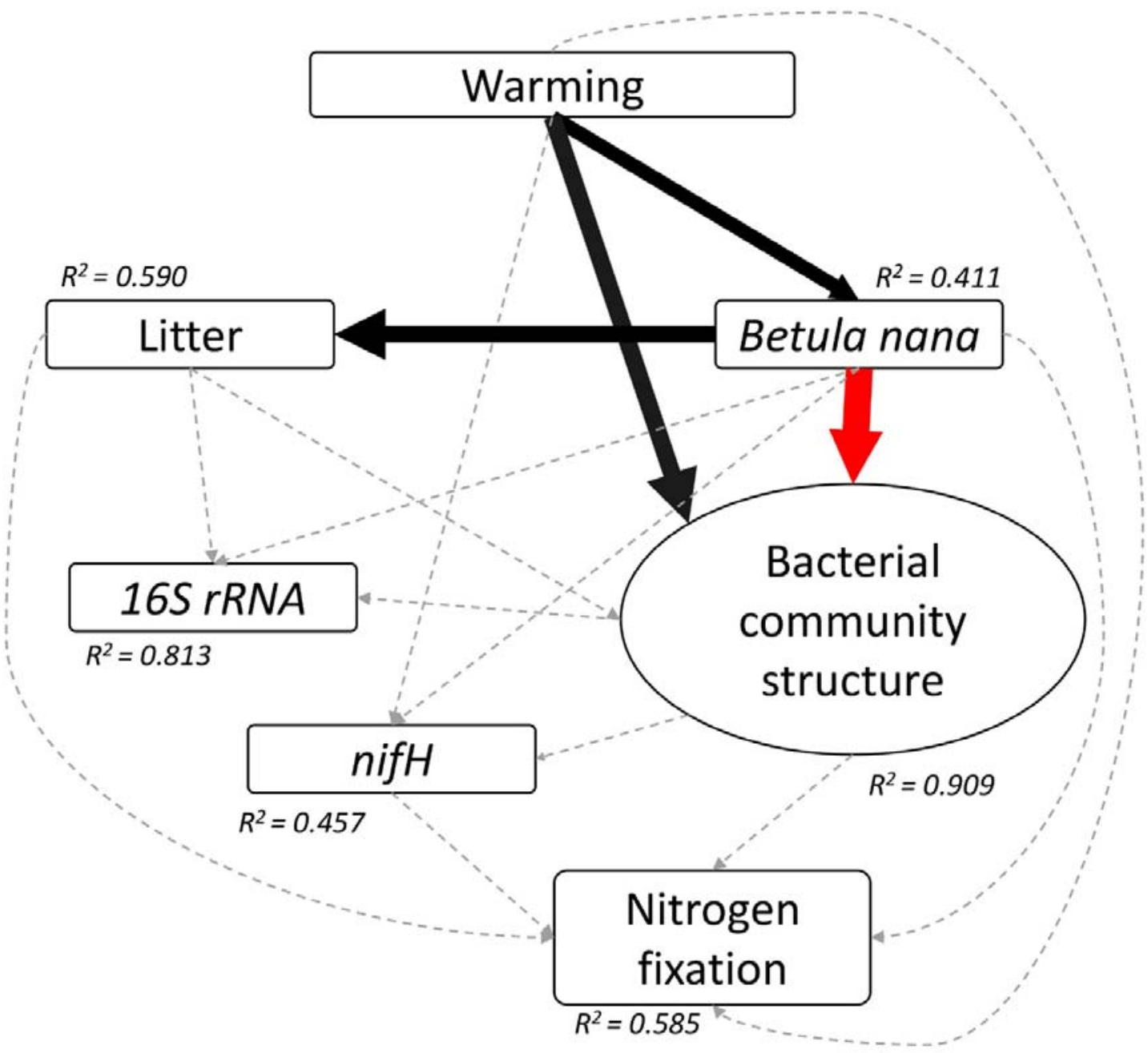

Figure 4 Structural equation model of relationships between warming, Betula nana and litter abundance, moss-associated bacterial community and $\mathrm{N}_{2}$-fixation. A latent variable (bacterial community structure) was computed to represent $\beta$-diversity and Shannon diversity index for each plot. $\chi 2=2.896, P$-value $=0.894, \mathrm{df}=7$, GFI $=0.982, \mathrm{RMSEA}=0, \mathrm{TLI}=1.202$. Positive significant effects are represented in black and negative significant effects in red. The strength of the effect is visualized by the width of the arrow. The $\mathrm{R}^{2}$-value represents the proportion of total variance explained for the specific dependent variable. Dash $\square$ line arrows indicate non-significant effects. Standardized path coefficients are presented in Table S3. 